\title{
Development of a Hydrous Ethanol Fuel Feeding Device for Spark- Ignition Engine
}

\author{
Alexis T. Belonio ${ }^{1, *}$, Manuel Jose C. Regalado ${ }^{1}$, Neil Caesar M. Tado ${ }^{1}$ and \\ Emmanuel V. Sicat ${ }^{2}$ \\ ${ }^{1}$ Philippine Rice Research Institute (PhilRice), Science City of Munoz, Nueva Ecija, Philippines \\ ${ }^{2}$ Phil-Sino Center for Agricultural Technology (PhilScat), Science City of Munoz, Nueva Ecija, Philippines
}

\begin{abstract}
While the Philippine Biofuels Act of 2006 mandates the use of anhydrous bioethanol as blend for gasoline, the potential of hydrous ethanol as an alternative fuel for spark-ignition engines has not been fully realized. This study explored the possibility of using hydrous ethanol as fuel for spark-ignition engines with minimal modifications and without the need for gasoline blend.

A fuel feeding device was developed to feed hydrous ethanol fuel into the intake manifold of the engine, bypassing the carburetor. By replacing the components that are not compatible with hydrous ethanol and installing a fuel feeding device developed at PhilRice, two spark-ignition engines were able to run solely on $80-95 \%$ hydrous ethanol fuel. The fuel economy was found to be a significant issue in the utilization of hydrous ethanol fuel as there is a $75 \%$ increase in fuel consumption when using hydrous ethanol. There is potential for hydrous ethanol to be used as fuel if it can be produced locally and sold at half the pump price of gasoline.
\end{abstract}

Keywords: Hydrous ethanol, fuel feeding device, spark ignition engine.

\section{INTRODUCTION}

The world's increasing consumption of nonrenewable petroleum-based fuel, which has already brought adverse environmental and economic impacts, has instigated researches and policies towards the use of clean, alternative and renewable energy. In the Philippines, the Biofuels Act of 2006 aimed to stimulate the production of bioethanol as an alternative to gasoline. Bioethanol (ethyl alcohol), is made from biomass through biological processes [1]. Bioethanol can either be hydrous (95\% purity) or anhydrous (99\% purity). The law specifically mandated the use of $10 \%$ anhydrous bioethanol as a blend with gasoline. At this level, existing spark-ignition engines can operate without negative effects on its performance and durability.

Anhydrous bioethanol, which contains less than 1\% water, is an anti-knock additive that is blended with gasoline and can be produced through complex process of distillation and dehydration. Several largescale bioethanol projects were implemented employing large distillation plants with thousands of hectares of service areas for feedstock production. Even with these huge projects, the Philippines still imports majority of its anhydrous bioethanol requirement. The concept of a centralized bioethanol production system has not been

*Address correspondence to this author at the Philippine Rice Research Institute, Science City of Munoz, Nueva Ecija, Philippines:

Tel: +6344-456-0285; Fax: +6344-456-0112;

E-mail: prri@email.philrice.gov.ph very successful. Problems arise when lands originally dedicated to producing food were converted into plantations of fuel crops such as corn, sugarcane, sweet sorghum. This caused skyrocketing food prices in the world market. While production of anhydrous bioethanol requires sophisticated equipment and largescale plants to operate, the potential of using hydrous bioethanol has not yet been fully realized.

Hydrous bioethanol can be produced by simple distillation and smaller equipment and thus can be applied to a decentralized and farm-based production system that can be operated by farmer groups althroughout the country depending on the availablity of feedstock for production. Hydrous bioethanol has a huge potential if it can be utilized in small spark-ignition engines that are commonly used by Filipino farmers. It has been sidelined in the Biofuels act for questions on its miscibility with gasoline.

The current engine designs are not compatible for using solely ethanol as fuel. One of the common problems associated with using ethanol fuel is its compatibility with metallic and rubber materials in the engine. In Brazil, this problem has been solved with the use of flexible-fuel vehicles. These vehicles have the ability to run on a variety of fuel from pure ethanol, gasoline or any combination of both [2]. This is achieved with the complex engine that automatically adjusts fuel injection and spark timing with the kind of fuel it detects. 
However, in the Philippine agricultural setting,a much simpler approach is applicable. Most sparkignition engines that are used by farmers are single cylinder with lower power ratings. Hydrous ethanol can be used as fuel if the compatibility issues are addressed properly. It would not be economical to replace the existing engines with the more costly flexfuel ones. The more logical solution would be to retrofit existing farmers' engines to enable it to run on hydrous ethanol as well as gasoline, whichever is more economical.

This study was conducted to enable spark-ignition engines to operate on hydrous ethanol fuel.Specifically, it aimed to develop a device that can be retrofitted to a conventional spark-ignition engine to adapt it for hydrous ethanol fuel. It also addressed the common material compatibility issues by replacing engine parts with ethanol-ready materials.

\section{LITERATURE REVIEW}

\section{Fuel Ethanol Production}

Ethanol in its liquid form is called ethyl alcohol which can be used as fuel when blended with gasoline or in its original state [3]. It is produced with the action of yeast on the sugar from cereal grains, sugar cane, fruit products and high cellulosic materials [4].

Ethanol is extracted through the process of distillation. It utilizes the differing vapor pressures and boiling points of water and ethanol. In atmospheric conditions, water boils at $100^{\circ} \mathrm{C}$, while ethanol boils at $78^{\circ} \mathrm{C}$. The boiling point of an ethanol-water mixture varies depending on the ethanol concentration of the mixture and falls somewhere between the boiling points of the individual components. Ethanol has a higher vapor pressure than water, which means that it needs lower energy change it from liquid to gas. In distillation, the mixture is heated so that the ethanol with higher vapor pressure is evaporated leaving more water in the mixture [5].

However, during distillation a point wherein the vapor boiling from the liquid was of the same composition as the liquid from which it was being generated. This is called the azeotropic ethanol-water mixture wherein the boiling points of the individual components are the same. This is achieved when the ethanol concentration reaches $95.6 \%$. This is also regarded as the hydrous fuel-ethanol that can be used in flexi-fuel engines. The production of anhydrous ethanol or pure (99-100\%) ethanol requires another process aside from distillation to dehydrate the remaining $5 \%$ water in the azeotropic ethanol-water mixture [6].

\section{Ethanol as Fuel for Spark Ignition Engines}

Bradley and Runnion [7] found that ethanol can replace gasoline in modified spark-ignition engines. However, it can be used in unmodified engines when blended with gasoline up to $20 \%$ ethanol content. Blending ethanol with gasoline enhance the octane rating of the fuel. A study conducted by Curran [8] used a fuel blend of $85 \%$ ethanol and $15 \%$ gasoline on a carbureted Briggs and Stratton engine. Material compatibility issue, lowered air to fuel ratio, and possible cold start were the major problems associated with the use of ethanol as fuel. Fuel consumption was not significantly increased during the tests.

The prospect of using solely hydrous ethanol as fuel for spark-ignition engines is yet to be exploited. Hydrous ethanol, which contains $5 \%$ water, was once used as fuel during the early years of automobile development. Henry Ford's Model T, which was produced from 1908 to 1925 and fitted with an adjustable jetting, ran on either gasoline, alcohol or a combination of both [9]. Henry Ford went further by branding ethanol as the "fuel of the future" and that fuel can be found in "every bit of vegetable matter that can be fermented" [5]. This only proves the feasibility of hydrous ethanol as a replacement for gasoline.

The performance of hydrous ethanol is always being compared with gasoline. At low engine speeds, the torque and Brake Mean Effective Pressure (BMEP) were higher when using anhydrous ethanol-gasoline blend compared with hydrous ethanol. However, at high engine speeds, higher torque and BMEP are achieved using hydrous ethanol. Subsequently, the Carbon Monoxide and hydrocarbon emissions are lower in hydrous ethanol, but there is an increase in Carbon Dioxide and Nitrous Oxide emissions [10].

When using fuels that are blended with $20 \%$ ethanol or higher, conventional engines must be retrofitted since ethanol corrodes certain rubber and other mild steel material in the fuel tank and carburetor. Furthermore, when using carbureted engines, a larger carburetor jet with $30-40 \%$ size increase is necessary to fuel purely ethanol. Cold starting problems, however, occur at temperatures of $13^{\circ} \mathrm{C}$ or lower. Changes in the compression ratio and spark timing are also needed to optimize the performance of ethanol fuel [11]. 


\section{Hydrous Ethanol-Gasoline Fuel Blends}

Hydrous ethanol concentrated to $95.6 \%$ using azeotropic distillation purity is completely miscible with gasoline. The gasoline-hydrous ethanol blend also do not exhibit phase separation under ambient and refrigerated conditions. A gasohol blend of $80 \%$ gasoline and $20 \%$ hydrous ethanol has a comparative performance with the commercial gasoline sold at the pumps. Hydrous ethanol-gasoline blends also exhibit a reduced $\mathrm{CO}, \mathrm{CO}_{2}, \mathrm{NO}_{\mathrm{x}}$ and $\mathrm{SO}_{2}$ exhaust emissions [12].

\section{Hydrous Ethanol Fuel: The Brazilian Model}

Aside from the US which uses E85 (85\% anhydrous ethanol and $15 \%$ gasoline) fuel, Brazil has made a head start in the promotion and utilization of hydrous ethanol as fuel. Flexi-fuel engines which run equally well on pure hydrous alcohol, pure gasoline, or gasoline-anhydrous alcohol blends, have been launched. This technology is compatible with a wide variety of ethanol-gasoline fuel ranging from $100 \%$ hydrous ethanol to a mix of $80 \%$ gasoline and $20 \%$ anhydrous ethanol. These engines automatically adjust their settings in relation to the type of fuel that is fed into the intake manifold [13]

Another major breakthrough in Brazil is in the economics of using hydrous ethanol fuel. Hydrous ethanol is sold at the pumps at $50-60 \%$ of the gasoline price. The lower ethanol prices tend to take into account that hydrous ethanol fuel consumption is $30 \%$ higher than that of gasoline [13].

\section{MATERIALS AND METHODS}

\section{Design Criteria for Fuel Feeding Device}

The major issue with fuel ethanol is its corrosive effects on metals and rubber in conventional sparkignition engines. The design concept of this device is to to inject ethanol into the combustion chamber, without the need of passing through the carburetor, thus eliminating the corrosion problems commonly encountered with hydrous ethanol fuel.The fuel tank was replaced with stainless steel material and the rubber fuel hose with polyurethane tube. The fuel feeding device would depend on the suction capability of the piston during combustion for conveying fuel into the intake manifold. The simple design allows it to be fabricated in local metalfoundry shops and be easily retrofitted to existing conventional spark-ignition engines.

\section{Retrofitting of Spark-Ignition Engines}

Two fuel feeding device were fabricated to retrofit two different spark-ignition engines - a $2.6 \mathrm{~kW}$ Robin and $4.8 \mathrm{~kW}$ Kenbo engine. The flanges of the fuel feeder were matched to the configuration of the carburetors of the two different engines. The device was bolted between the intake manifold and carburetor of the engines.

Table 1: Volume Composition of the Different Hydrous Ethanol Fuel and Gasoline

\begin{tabular}{|c|c|c|c|}
\hline Fuel Type & $\begin{array}{c}\text { Ethanol } \\
\text { Content (\%) }\end{array}$ & $\begin{array}{c}\text { Water } \\
\text { Content (\%) }\end{array}$ & $\begin{array}{c}\text { Heating Value } \\
\text { (MJ/kg) }\end{array}$ \\
\hline \hline he80 & 80 & 20 & 21.56 \\
\hline he85 & 85 & 15 & 22.91 \\
\hline he90 & 90 & 10 & 24.26 \\
\hline he95 & 95 & 5 & 25.60 \\
\hline Gasoline & - & - & 43.45 \\
\hline
\end{tabular}

\section{Engine Performance Using Hydrous Ethanol Fuel}

Tests were performed to determine engine performance with varying hydrous ethanol fuel. The 2.6 kW Robin engine was a low-speed engine with a 2:1 output speed reduction. The $2.6 \mathrm{~kW}$ Robin engine was coupled to $5 \mathrm{~cm}$ self-priming water pump and was operated using varying levels of hydrous ethanol- $80 \%$, $85 \%, 90 \%$ and $95 \%$ with water making up the remainder of the mixture. This is an exploratory study to determine the ability of the engine to run on hydrous ethanol fuel of lesser purity than the azeotropic 95\% level. Furthermore, the engine was operated using gasoline fed to the intake manifold through the carburetor as a control treatment. The water discharge was measured using a triangular weir and computed using the formula:

$Q=0.0138 \mathrm{H}^{5 / 2}$

Where

$\mathrm{Q}=\quad$ is the discharge, (lps)

$\mathrm{H}=\quad$ is the head, $\mathrm{cm}$

The 4.8 kW Kenbo engine was tested using a water brake dynamometer at PhilScat using both 95\% hydrous ethanol and gasoline fuel. The tests were conducted at full throttle as specified by the PAES (Philippine Agricultural Engineering Standard) 
117:2000. However, due to limitations in the capability of the dynamometer, the actual power output of the engine was not measured. The engines were applied with varying loads to reduce the speed at four different levels. Figure 1 shows the set-up of the engine attached to the dynamometer. The fuel consumption at different engine speeds and load applied was measured. It should be noted that the load applied using the water brake is just a fraction of the total power output of the engine.

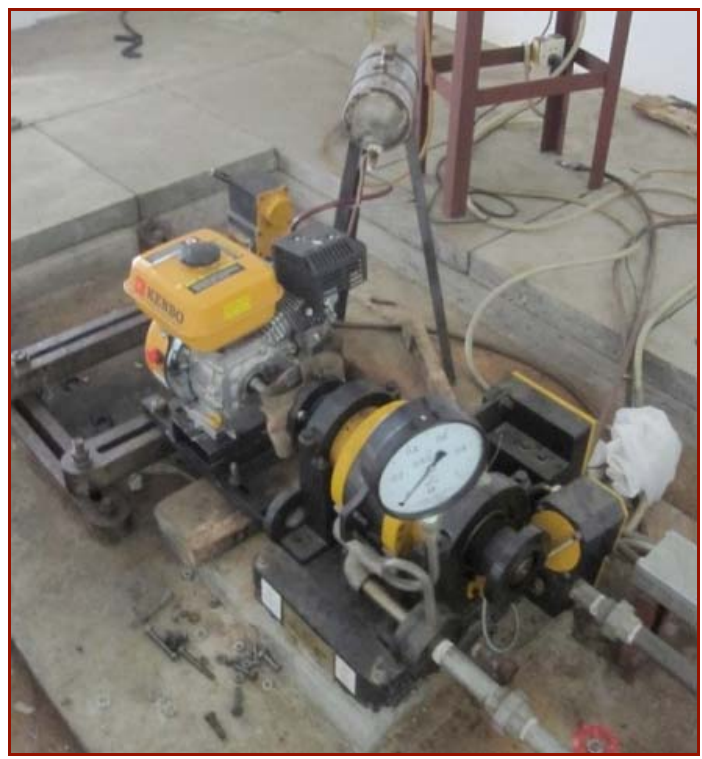

Figure 1: Engine attached to the dynamometer.

\section{RESULTS AND DISCUSSION}

\section{Design of Fuel Feeding Device Assembly}

The fuel feeding device consists of a fuel tank, fuel line, fuel feeding regulator and spray nozzle. The fuel tank is a stainless steel cylinder that serves as a container of the hydrous ethanol fuel. It is connected to the fuel feeder by a polyurethane tube that serves as fuel line in replacement of the conventional rubber hose. The fuel feeder is a screw-type gas valve control feeder that has a conical pin (c) for constricting fuel flow and a circular knob (a) at the end as a control lever. The spray nozzle assembly consists of a duct that is flanged (e) at both ends for attachment between the intake manifold and carburetor. It has a hairlinethick hole (d) drilled perpendicular to the duct acting as a fuel orifice to atomize the fuel entering the intake manifold.

Fuel ethanol from the tank enters the fuel feeding device through the pipe inlet (b). The amount of fuel intake is controlled by the clearance of the pin at the bottom of the fuel feeder. Ambient air enters through the air cleaner and carburetor of the engine where air intake is controlled.

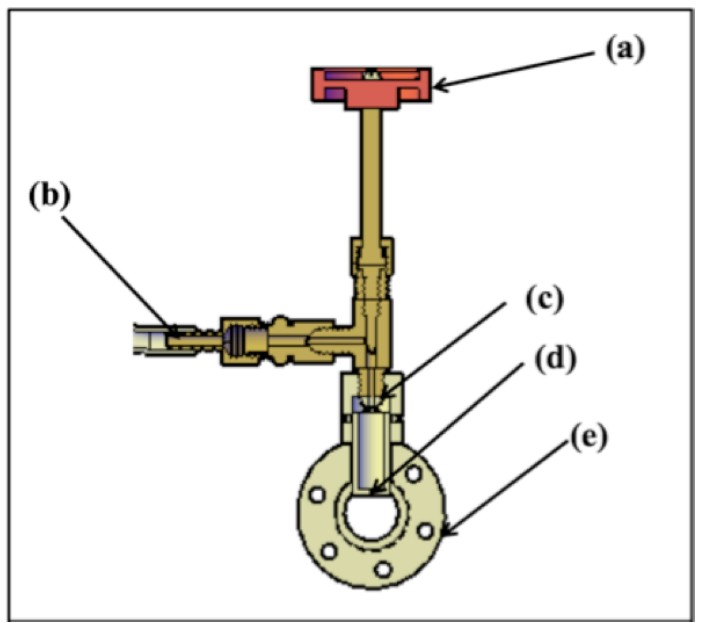

Figure 2: Section view of the fuel feeding device.

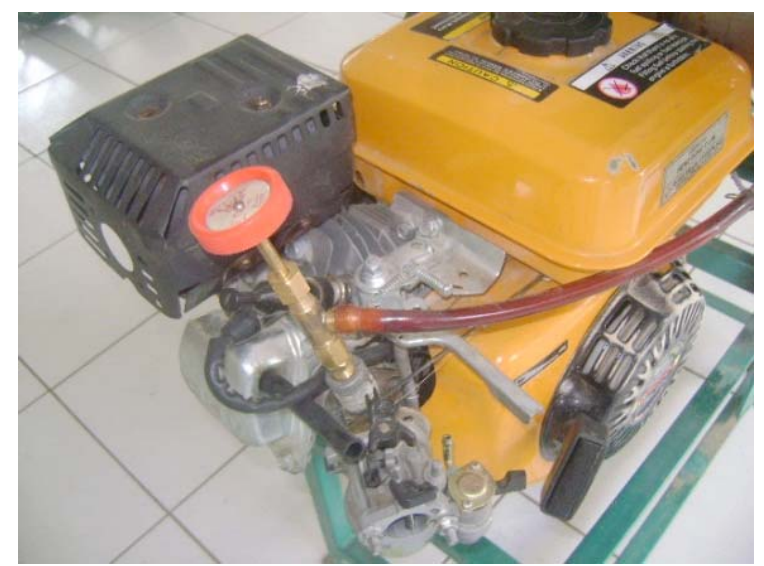

Figure 3: $4.8 \mathrm{~kW}$ Kenbo engine retrofitted with hydrous ethanol fuel feeding device.

\section{Water Pumping Using Varying Hydrous Ethanol Fuel}

This test determined the ability of the engine to run solely on hydrous ethanol at different purity. The engine was able to operate on varying levels of hydrous ethanol fuel. Cold starting problems were encountered when using he80 and he85 fuel. Furthermore, the engine speed was erratic due to difficulty in burning the fuel with high water content. The engine was able to operate smoothly on he90 and he95 fuel with the speed sustained at the desired level.

Figure 4 shows the water pumping rate at different engine speeds using the different fuel types. It shows an increase in water flow rate with the increase in engine speed. Table 3 shows the fuel consumption at different engine speed settings. It shows that he80 fuel 
Table 2: Observations on the Engine Operation using Hydrous Ethanol Fuel

\begin{tabular}{|c|c|}
\hline Fuel Type & Observations \\
\hline \hline he80 & $\begin{array}{c}\text { Cold starting problems were encountered; engine } \\
\text { was able to operate with this fuel but with } \\
\text { unstable engine speed }\end{array}$ \\
\hline he85 & $\begin{array}{c}\text { Cold starting problems were encountered; engine } \\
\text { was able to operate with this fuel but with } \\
\text { unstable engine speed }\end{array}$ \\
\hline he90 & Easy starting; engine speed is sustained \\
\hline he95 & $\begin{array}{c}\text { Easy starting; engine speed is sustained, fuel is } \\
\text { burned completely (no ethanol odor observed) }\end{array}$ \\
\hline
\end{tabular}

has the highest fuel consumption at $1.8 \mathrm{~L} / \mathrm{h}$ at 3600 $\mathrm{rpm}$ and $3 \mathrm{~L} / \mathrm{h}$ at $4800 \mathrm{rpm}$. Gasoline has the least fuel consumption at $0.7 \mathrm{~L} / \mathrm{h}$ at $3600 \mathrm{rpm}$ and $1.08 \mathrm{~L} / \mathrm{h}$ at $4800 \mathrm{rpm}$. At all engine speed settings, fuel consumption using he 80 and he 85 are not significantly different.

Among the different hydrous ethanol fuel used, he95 showed the least fuel consumption that can be attributed to its higher heating value and lower water content than the other hydrous ethanol fuel. However, there is no significant difference in fuel consumption between he90 and he95 fuel. On the other hand, gasoline fuel consumption if significantly different from all the hydrous ethanol fuels. This can be attributed to the difference in energy content of gasoline as compared to hydrous ethanol. Gasoline has a heating value of $43.45 \mathrm{MJ} / \mathrm{kg}$ while he95 has $25.60 \mathrm{MJ} / \mathrm{kg}$.

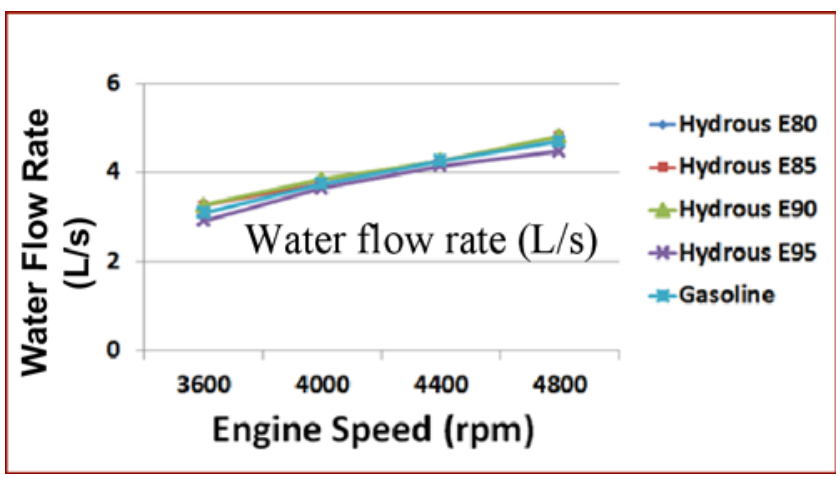

Figure 4: Fuel Influence on water flow rate.

This test was conducted to determine engine performance at varying load application. The $4.8 \mathrm{~kW}$ Kenbo engine was run at full throttle and applied with load at the water brake to achieve to desired engine speed. Figure 5 shows the torque developed at the water brake as the engine speed was set at different levels. Higher torque measurements were observed at lower engine speeds. The highest torque measured was that of gasoline at an engine speed of $2800 \mathrm{rpm}$. Comparison of means using Tukey's Studentized Range (HSD) Test found no significant difference in the torque applied at the brakes at all the engine speed settings.

Table 3: Fuel Consumption at Different Engine Speeds*

\begin{tabular}{|c|c|c|c|c|}
\hline \multirow[t]{2}{*}{ Fuel } & \multicolumn{4}{|c|}{ Fuel consumption (L/h) } \\
\hline & $\begin{array}{l}3600 \\
(\mathrm{rpm})\end{array}$ & $\begin{array}{l}4000 \\
\text { (rpm) }\end{array}$ & $\begin{array}{l}4400 \\
(\mathrm{rpm})\end{array}$ & $\begin{array}{l}4800 \\
\text { (rpm) }\end{array}$ \\
\hline he 80 & $1.8^{\mathrm{a}}$ & $2.13^{a}$ & $2.53^{\mathrm{a}}$ & $3.00^{a}$ \\
\hline he85 & $1.67^{\mathrm{a}}$ & $1.95^{\mathrm{a}}$ & $2.30^{\mathrm{a}}$ & $2.65^{\mathrm{ab}}$ \\
\hline he90 & $1.54^{\mathrm{ab}}$ & $1.67^{b}$ & $2.10^{\mathrm{ab}}$ & $2.28^{\mathrm{ab}}$ \\
\hline he95 & $1.26^{\mathrm{b}}$ & $1.55^{b}$ & $1.80^{\mathrm{b}}$ & $2.10^{\mathrm{b}}$ \\
\hline Gasoline & $0.70^{\mathrm{c}}$ & $0.80^{c}$ & $0.90^{c}$ & $1.08^{\mathrm{c}}$ \\
\hline
\end{tabular}

*Mean values with the same small letter within the column are not significantly different at $p=0.05$.

Engine dynamometer testing.

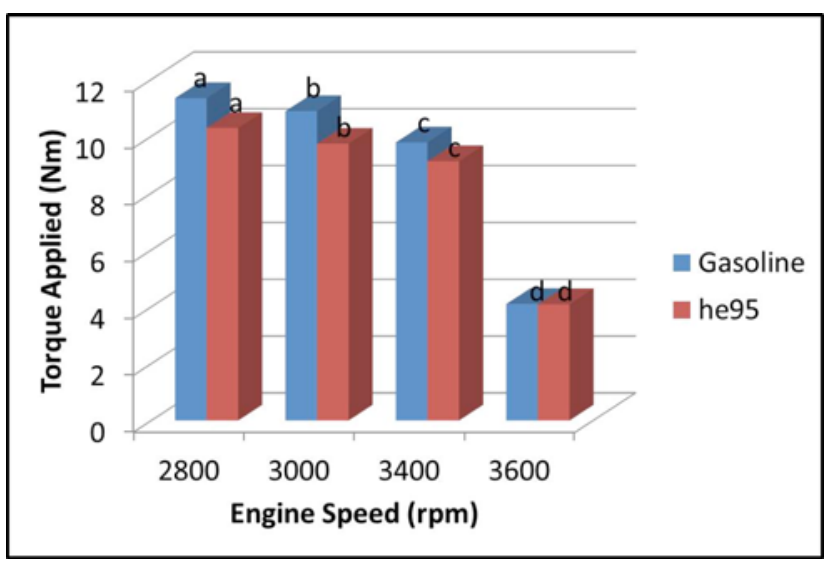

Figure 5: Load applied at the water brake at different engine speed.

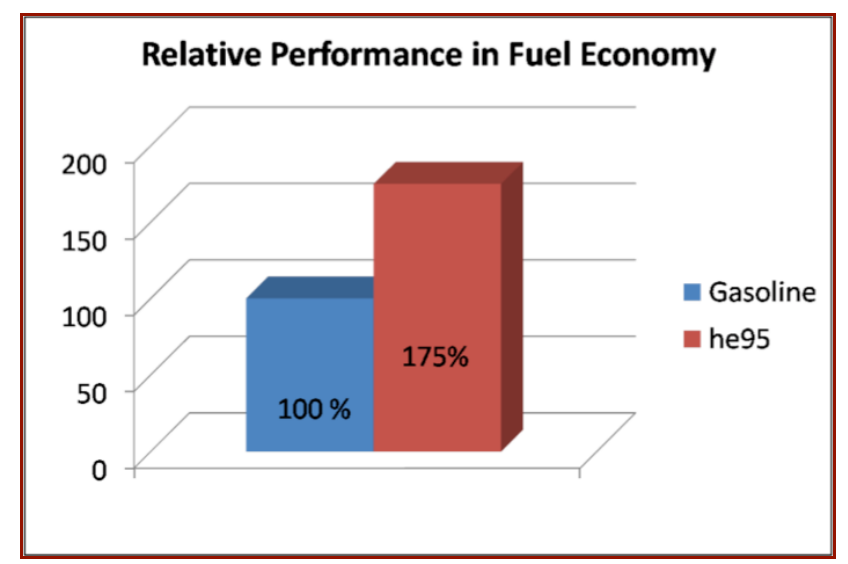

Figure 6: Relative performance of he95 fuel in terms of fuel economy with gasoline.

Figure 6 shows the relative performance of he95 fuel in terms of fuel economy. The data show a $75 \%$ 
increase in fuel consumption when using he95 as fuel as compared to gasoline. This can be attributed to the energy content of the two fuels. Gasoline contains $62 \%$ more energy that the he95 fuel, hence this is compensated through the higher fuel feeding of hydrous ethanol. In this study, the fuel feeding mechanism has only been the major difference from the operation of conventional engines. The engines were operated at the settings intended for carbureted gasoline use. There were no modifications done on the spark timing and compression ratio of the engine- both of which have a direct effect on the engine performance. This was primarily due to the consideration of ease of retrofitting and adoption of the technology for farmers in far-flung areas where gasoline supply is scarce.

\section{Cost Comparison between Hydrous Ethanol and Gasoline}

The source and cost of fuel is a major drawback in adopting the use of hydrous bioethanol as fuel. Fuelgrade hydrous bioethanol (he95) production is yet to be commercially available. The Philippines currently import $75 \%$ of its anhydrous bioethanol requirement at Php 30 per liter. Local production of the same fuel costs higher at Php 47 per liter [14]. Hydrous ethanol does not require the costly second stage of dehydration in anhydrous ethanol production, thus costs can be greatly reduced. Results from this study show that the cost of hydrous bioethanol should be $50 \%$ lower than that of gasoline to deflect the fuel economy issue.

\section{CONCLUSION}

This study established that hydrous ethanol can be fueled solely in spark-ignition engines without the need for blending it with gasoline. The fuel feeding device developed achieved its purpose of conveying hydrous ethanol fuel to the intake manifold of the engine without passing it through the carburetor. Its flanged design enabled it to be bolted between the carburetor and intake manifold, thus maintaining the parts of the conventional engine and allowing easy switching of fuel from hydrous ethanol to gasoline.

The study also established that hydrous ethanol of lower purity up to $80 \%$ can be fueled to the engine, but with drawbacks in the engine performance. This implies that fuel for farming can be produced at the village level even when using simple distillation equipment that can produce hydrous ethanol from $80 \%-95 \%$ purity. This would favor decentralized energy production system for farming areas with source of different feedstock for bioethanol production. However, there is a significant difference in fuel economy when using he80-85 and he90-95.

The best hydrous ethanol fuel to use would be the $90-95 \%$ hydrous ethanol. Results also showed that the fuel economy of $95 \%$ hydrous ethanol is $75 \%$ higher than that of gasoline. Thus, the hydrous ethanol should be $50 \%$ cheaper than gasoline for it to be competitive in the market. This study has been conducted to develop a technology for hydrous bioethanol fuel use in preparation to the event when gasoline would cost higher than ethanol.

\section{RECOMMENDATIONS}

It is recommended that further studies should be conducted with the use of hydrous bioethanol as fuel. Important factors should be considered such as ignition timing and engine compression ratio. There should be further studies to look into the optimum engine settings intended for the use of hydrous bioethanol fuel. A more detailed testing should be done on the engine with AMTEC to ensure it can operate with hydrous bioethanol fuel according to the Philippine standards. The engine should be subjected to season-long field testing to fully evaluate its economic viability.

\section{REFERENCES}

[1] Biofuels Act of 2006. [Internet] 2006. [cited 2014 Apr 10]. Available from: http://www.senate.gov.ph/ republic_acts/ra\% 209367.pdf

[2] Flexible Fuel Vehicle. 2014. [cited 2014 Apr 10]. Available at: http://en.wikipedia.org/wiki/ Flexible-fuel_vehicle

[3] Clean Fuel Development Coalition. Ethanol-Blended Fuels [Internet] 2014. [cited cited 2014 Apr 10]. Available from: www.cleanfuelsdc.org

[4] Miller DL. Ethanol Fermentation and Potential. Biotechnol Bioenerg Symp 1975; 5: 345-352.

[5] Freudenberger R. A Guide to Small-scale Ethanol Alcohol Fuel. Gabriela Island: New Society Publishers 2009.

[6] Madson PW. Ethanol Distillation: The Fundamentals. The Alcohol Textbook $4^{\text {th }}$ Edition. Nottingham: Nottingham University Press 2003.

[7] Bradley C, Runnion K. Understanding Ethanol Fuel: Production and Use [Internet]. 1984 [cited 2014 Apr 10]. Available from: Pr-info@vita.org

[8] Curran S. Retrofit of a Briggs \& Stratton Small Engine to Run E85. Paper presented at: Proceedings of the National Conference on Undergraduate Research (NCUR); 2006 April 6-8; University of North Carolina at Ashville, North Carolina, USA.

[9] Common ethanol fuel mixtures [Internet] 2014. [cited 2014 Apr 10]. Available from: http://en.wikipedia.org/wiki/ Common_ethanol_fuel_mixtures

[10] Costa RC, Sodre JR. Hydrous Ethanol vs Gasoline-Ethanol Blend: Engine Performance and Emissions. Fuel 2010; (89): 287-293.

http://dx.doi.org/10.1016/j.fuel.2009.06.017 
[11] Rutz D, Janssen R. Biofuel Technology Handbook. Munich: WIP Renewable Energies 2007.

[12] Agrupis SC. Hydrous Ethanol Biofuel Research at MMSU Towards A Greener Philippines. Paper presented at: The National Research Conference on Agricultural Sustainability; 2013 November; Central Luzon State University, Science City of Munoz, Philippines.
[13] Lyons TP. Ethanol around the world: rapid growth in policies, technology and production. The Alcohol Textbook 4th Edition. Nottingham: Nottingham University Press 2003.

[14] Ng, Ester. Asian Ethanol Mandates Shifting Goalposts. 2014. [cited 2014 Apr 10]. Available at: http://www.platts.com/IM. Platts.Content \%5Caboutplatts $\% 5$ Cmediacenter $\% 5 \mathrm{Cpdf} \% 5$ Cinsight-oct13-goal posts.pdf 